\title{
Critical Success Factors of Sustainable Leadership: Evidence from High-achievement School
}

\author{
Mohd Faiz Mohd Yaakob ${ }^{1, *}$, Noor Hashimah Hashim ${ }^{2}$, Mat Rahimi Yusof ${ }^{1}$, Mohd Sofian Omar \\ Fauzee $^{1}$, Muhammad Noor Abdul Aziz ${ }^{1}$, Hareesol Khun-Inkeeree ${ }^{3}$, Akhmad Habibi ${ }^{4}$, \\ Khuan Wai Bing ${ }^{5}$ \\ ${ }^{1}$ School of Education and Modern Languages, Universiti Utara Malaysia, Malaysia \\ ${ }^{2}$ Institut Aminuddin Baki Cawangan Utara (IABCU), Kedah, Malaysia \\ ${ }^{3}$ School of Liberal Art, Wilalak University, Thailand \\ ${ }^{4}$ Faculty of Teacher Training and Education, Jambi University, Indonesia \\ ${ }^{5}$ Faculty of Economics and Management, Universiti Pendidikan Sultan Idris, Malaysia
}

Received September 27, 2019; Revised March 20, 2020; Accepted March 28, 2020

Copyright $\odot 2020$ by authors, all rights reserved. Authors agree that this article remains permanently open access under the terms of the Creative Commons Attribution License 4.0 International License

\begin{abstract}
This study aims to identify critical success factors of sustainable leadership success. A total of 629 teachers were involved in answering the questionnaires that were distributed. Meanwhile, 4 school principals and 8 teachers were involved in semi-structured interviews to support quantitative findings. The findings showed that all factors of sustainable leadership namely; Focus on Pupils, Lateral Capacity Building Through Networks, Sustain Work Positive Environment, Deep Learning, Intelligent Accountability and Vertical Relationships, and Commitment to Changing Context at All Levels, were practiced at high levels in the schools. Meanwhile, the qualitative findings support three critical success factors in sustainable leadership which are Sustain Work Positive Environment, Commitment to Changing Context at All Levels and Deep Learning. Thus, this study provides information to stakeholders and contribution to the academic research field.
\end{abstract}

Keywords Sustainable Leadership, Educational Administration, Educational Planning, Educational Planning and Policy

\section{Introduction}

The development and dynamics of education are demanding towards more integration and focused studies. Sustainable leadership refers to the ability of a leader in an organization to improve the achievement and sustain deep human values [1]. Meanwhile, leadership needs to be combined or integrated with ethical leadership practices such as friendly and trusting relationship, openness to school members, professional commitment and acting as a role model [2]. Consequently, sustainable leadership is crucial in ensuring that school excellence remains prolonged and this leadership is seen as a form of management aimed at maintaining excellence, enhancing creativity and employee innovation while upkeeping innovative workers in the organization to further enhance existing excellence. In general, this leadership is practiced from the automotive industry $[3,4]$ and currently being applied in the context of education [5-8].

Fullan[1] and Hargreaves and Fink[9] stated that sustainability does not only focus on maintaining a good program in an organization, but this involves serious initiatives that can be developed in the present and for future situations. In school context, this was also focused by Hallinger and Heck[10] who realized that leaders are able to influence members of the organization through three levels - direct impacts, indirect effects, and reciprocity effects. These three levels can be seen in leadership at schools.

\section{Research Question}

This study is guided by two main research questions:

a) What is the level of sustainable leadership from teacher's perspectives (high achievement school)?

b) What are the critical success factors of sustainable leadership from teachers' perspectives (high achievement school)? 


\section{Conceptual Framework}

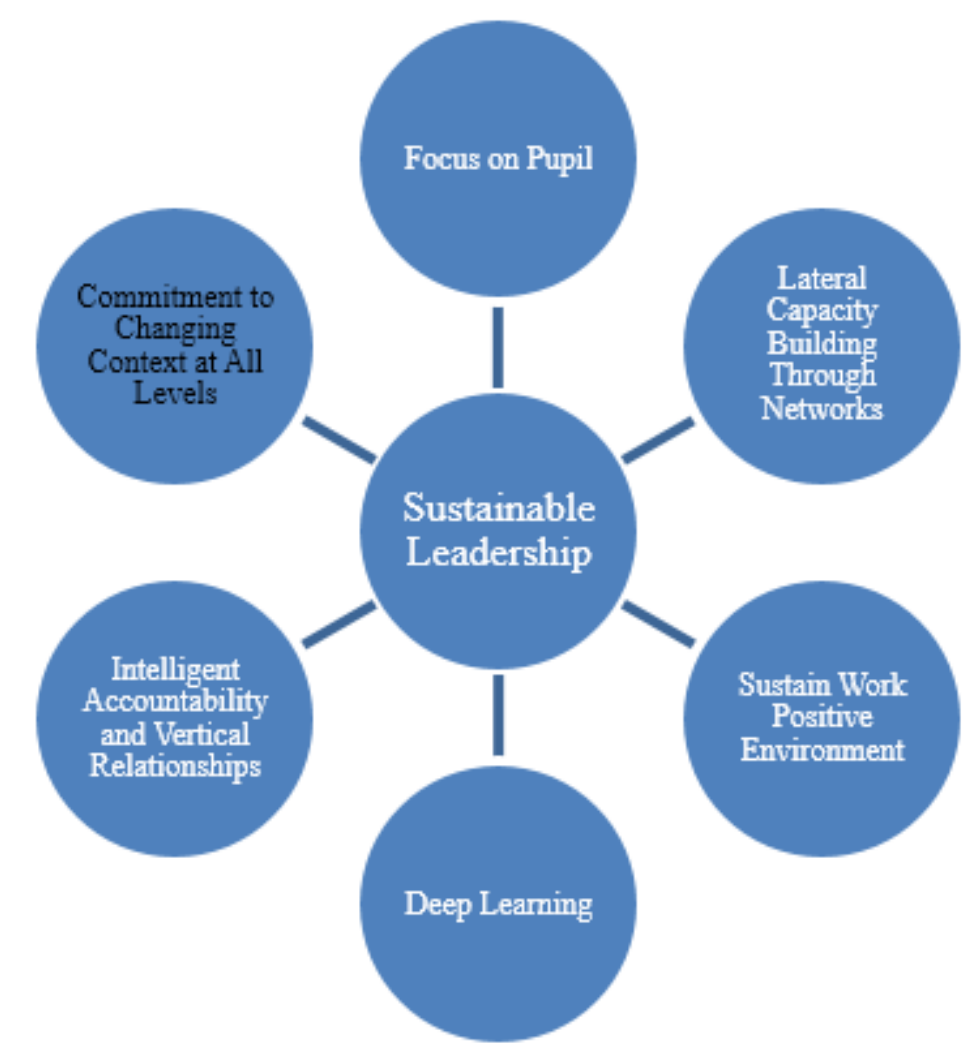

Figure 1. Conceptual Framework of Sustainable Leadership

\section{Literature Review}

\subsection{Focus on Pupils}

Pupils are the main focus of sustainable leadership. Pupil's inclusion is parallel with the philosophy of national education that is desired to be practiced at schools. An effective and brilliant school is a school that focuses on students as its top priority. This is because students are exhibited as customers who should be given priority, focus and attention in doing something. Based on this, Fullan[11] agrees that in order to improve the organization's achievement and to bridge the gap between the best and weakest students, value-related matters need to precede the will of the individual. Fullan[1] also discusses that the rights of pupils in school should be focused on the greatest opportunity in learning. This is parallel with the aspirations of the pupils depicted in Malaysia Education Blueprint (2012-2025) which emphasizes on the quality of the pupils to be achieved by every pupil in schools [12].

\subsection{Lateral Capacity Building through Networks}

Networking among staff in school is a collegiality. Collegiality plays an important role in the success of sustainable leadership. Friends who are always learning from one another as well as their dependency on each other's strengths and working together on the weaknesses will always result in teachers improving their professionalism. Mosley et al., [13] pointed out that visionary leaders will always create a platform for organization members to exchange views and share knowledge. According to Kruse et al., [14], the implementation of the Professional Learning Community at schools makes teachers work together more effectively in improving the quality of teaching to students. The culture of cooperation among organizations is also applied to ensure the development of individual competencies and is enhanced in parallel with organizational development [15]. Additionally, leaders in the school need to be wise in selecting and creating a solid team of teachers in their schools to make schools as a learning organization. Hargreaves[16] stated that organizational culture that emphasizes trust, cooperation and responsibility should be created to develop more knowledge and expertise among teachers.

\subsection{Sustain Work Positive Environment}

The working environment is divided into positive and negative attraction. In the context of sustainable leadership, a positive working environment is required. This element from sustainable leadership is related to the need for a positive working environment. Human resource is the most 
important asset in an organization. Everything from knowledge and skills has the potential to grow productively for success. Fullan[1] stated that every new idea is able to improve the organization's sustainability. This situation occurs at the school when the principal plays an important role in creating a working environment that encourages teachers to carry out their essential tasks by focusing more and generating new knowledge on teaching and learning. The sharing of vision for success among teachers and education leaders increase emotional cohesion between the two bridges as well as heighten the improvement and achievement of the organization [17].

\subsection{Deep Learning}

Aspects of teaching and learning are always the big focus. Education leaders who can preserve their school's excellence are leaders who focus on quality activities in the classroom. Additionally, a study with 12 high-performance schools in the UK showed that all the principals focused on quality teaching and learning [18]. Principals need to prioritize monitoring of teaching aspects and to hold discussions with teachers to solve arising problems immediately [19]. According to Hallinger and Lee[12] and Walker et al., [13], continuous support and monitoring from principals can improve the quality of teaching of teachers as well as the quality of learning among students.

\subsection{Intelligent Accountability and Vertical Relationships}

This element is related in providing coaching leaders among teachers as one of the factors to ensure the sustainability of an organization. Fullan[1] states that to ensure the sustainability of organizational achievement, leaders play an important role in realizing leadership co-operation. Leadership enables the expertise available in every teacher to be fully utilized at school. In order to develop a culture of preservation in schools, schools should not rely solely on a leader, but instead use the expertise, talent and leadership experience of other teachers at various levels and extents. The interactions that exist between teachers and principals during this leadership partnership have had an important and positive impact on teaching and learning activities in the classroom [14].

\subsection{Commitment to Changing Context at All Levels}

This element is closely linked by changing the context of work and culture at all levels to ensure the transformation take place continuously. However, in everyday practice, many of these elements are difficult to achieve as they involve many parties. And it takes a lot of time and effort to implement them. Fullan[1] and Davies[15] stated that strategic communication and interaction between members at all levels is capable of changing the context and culture of an organization. This will help stakeholders understand the actual situation more clearly.

\section{Methodology}

This study used a mixed-method approach that combined quantitative and qualitative methods. Researchers applied this approach as proposed by Creswell[16] and used the explanatory sequential design method as shown as Figure 2. The study started with quantitative method and further explained qualitatively. The quantitative method was implemented in the early stages using the survey design and subsequently, semi-structured interviews were conducted. This interview was conducted to support the findings in exploring and obtaining a more detailed data [17]. Qualitative findings are able to clarify more in-depth about the findings obtained through quantitative data [18].

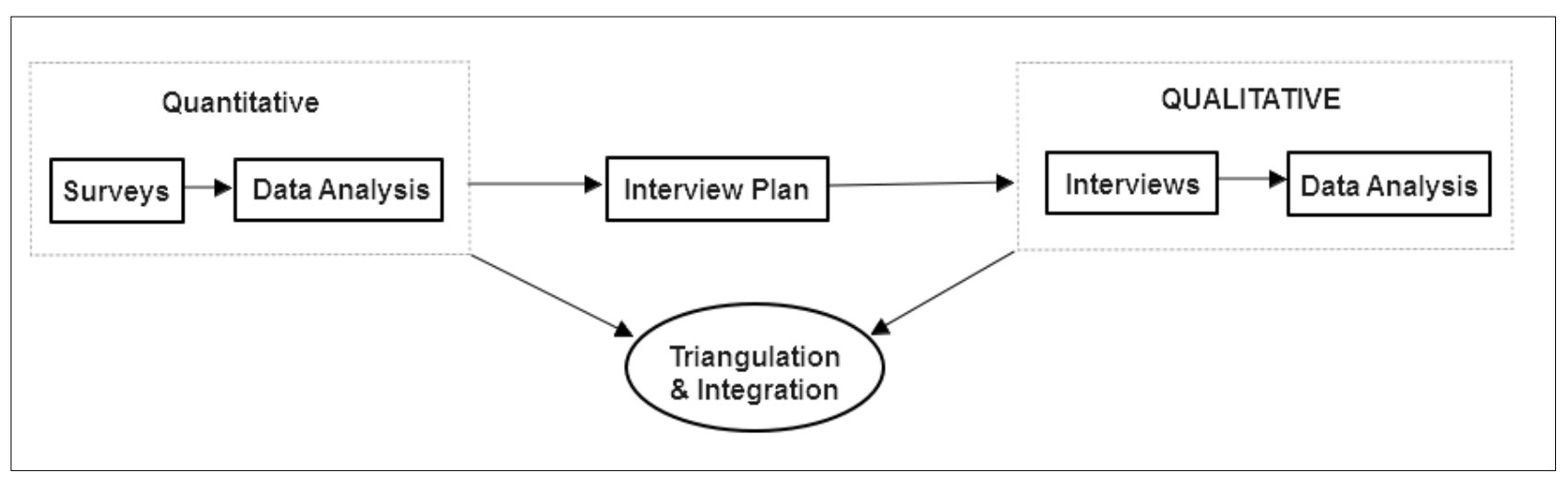

Figure 2. Explanatory sequential design method 


\subsection{Quantitative Study}

Researchers used a questionnaire to get feedback on sustainable leadership in schools. Teachers were randomly selected in answering this questionnaire. The questionnaire was based on sustainable leadership elements introduced by Fullan[1] and Hardie[7].

\subsection{Qualitative Study}

Questions for semi-structured interviews were built based on the dimensions as measured in the survey method. Researchers constructed semi-structured questions as a guideline for conducting interviews more smoothly and orderly in facilitating researchers to make important notes during the interviews.

\subsection{Validity and Reliability}

The most important thing in a research is to measure what is to be measured $[19,20]$. Reliability explains the extent to which an instrument, procedure or test is capable of producing the same results in various situations assuming that other things do not change. This reliability also refers to the consistency of a measuring instrument in evaluating what is to be measured $[21,20]$.

In the early stage, the questionnaire items were translated into Malay language using back-to-back translation method. Researchers sought cooperation from a certified officer at the Curriculum Development Division, Ministry of Education, who owned a certificate from the National Translation Institute, two lecturers from the Aminuddin Baki Institute (IAB) and an English language teacher.

In the second stage, a total of five teachers from national high schools comprising various races, namely Malay, Chinese and Indians were selected to examine the entire instrument in terms of typeface, size and language layout. This was to determine whether they were clear with the language used. From their feedback, some improvements were made. For instance, the word 'organization' was changed to 'school'. Later, the researchers submitted the questionnaire to two Malay language experts (Munsyi Dewan).

In the third level, researchers managed to get seven experts who had extensive knowledge in the areas of management, administration and education leadership as expert validation. This stage involved lecturers from IAB, district officers, principals and university lecturers from others government universities. Then, the researchers conducted a pilot study to validate the questionnaire in terms of its content. The finding of the reliability is shown in Table 1.

Table 1. The Reliability of Sustainable Leadership Instruments

\begin{tabular}{|c|c|c|c|c|c|}
\hline No Item & Cronbach Alpha if Deleted & Dimension & Cronbach Alpha & Construct & Cronbach Alpha \\
\hline B1 & 0.837 & & & & \\
\hline B2 & 0.861 & & & & \\
\hline B3 & 0.843 & Foruc on Punils & 0871 & Sustainable & 0.054 \\
\hline B4 & 0.831 & Focus on Pupils & $0.8 / 1$ & Leadership & 0.954 \\
\hline B5 & 0.855 & & & & \\
\hline B6 & 0.866 & & & & \\
\hline B11 & 0.849 & \multirow{6}{*}{$\begin{array}{l}\text { Lateral Capacity Building } \\
\text { Through Networks }\end{array}$} & \multirow{6}{*}{0.864} & & \\
\hline B12 & 0.845 & & & & \\
\hline B13 & 0.836 & & & & \\
\hline B14 & 0.823 & & & & \\
\hline B15 & 0.830 & & & & \\
\hline B16 & 0.863 & & & & \\
\hline B17 & 0.792 & \multirow{4}{*}{$\begin{array}{l}\text { Sustain Work Positive } \\
\text { Environment }\end{array}$} & \multirow{4}{*}{0.853} & & \\
\hline B18 & 0.775 & & & & \\
\hline B19 & 0.802 & & & & \\
\hline B20 & 0.871 & & & & \\
\hline B21 & 0.611 & \multirow{6}{*}{ Deep Learning } & \multirow{6}{*}{0.680} & & \\
\hline B22 & 0.607 & & & & \\
\hline B23 & 0.618 & & & & \\
\hline B24 & 0.594 & & & & \\
\hline B25 & 0.780 & & & & \\
\hline B26 & 0.648 & & & & \\
\hline B27 & 0.857 & \multirow{4}{*}{$\begin{array}{l}\text { Intelligent Accountability and } \\
\text { Vertical Relationship }\end{array}$} & \multirow{4}{*}{0.840} & & \\
\hline B28 & 0.735 & & & & \\
\hline B29 & 0.826 & & & & \\
\hline B30 & 0.758 & & & & \\
\hline B31 & 0.815 & \multirow{6}{*}{$\begin{array}{l}\text { Commitment to Changing Context } \\
\text { At All Levels }\end{array}$} & \multirow{6}{*}{0.818} & & \\
\hline B32 & 0.808 & & & & \\
\hline B33 & 0.821 & & & & \\
\hline B34 & 0.761 & & & & \\
\hline B35 & 0.752 & & & & \\
\hline B36 & 0.765 & & & & \\
\hline
\end{tabular}


The results from the pilot study showed that the value of reliability based on Cronbach Alpha obtained was 0.954. This finding demonstrates the reliability of Cronbach Alpha above 0.70 and is appropriate for research purposes [22]. The interview findings obtained from four principals and eight teachers were analyzed by the researchers. The results of the interview were transmitted in verbatim and placed with appropriate codes. Once the coding process was completed, the researchers asked the views and expert opinions of two professionals in the field of education management to examine and evaluate each category. These two experts acted as inter-rater to verify the categories that researchers had done. Subsequently, the researchers made calculations based on Cohen Kappa[23] for qualitative data as shown in Table 2 .

Table 2. Results of Kappa's Reliability Test on Interview Findings

\begin{tabular}{|c|c|c|c|}
\hline \multirow{2}{*}{ Finding } & \multirow{2}{*}{ Value } & \multicolumn{2}{|c|}{ Kappa's Reliability } \\
\cline { 3 - 4 } & & $\begin{array}{c}\text { Landis \& Koch } \\
\text { (1977) }\end{array}$ & Chua (2012) \\
\hline Interview & 0.82 & $\begin{array}{c}\text { Almost perfect } \\
\text { agreement }\end{array}$ & $\begin{array}{c}\text { High and very } \\
\text { satisfying }\end{array}$ \\
\hline
\end{tabular}

\subsection{Sample and Population}

The study involved national high schools in band 2 and 3 in the northern peninsula. A total of 42 schools and 629 teachers were involved. On the hand, semi-structured interviews included four principals and eight teachers. These principals and teachers were selected from four different schools.

129 teachers comprising $20.5 \%$ were male teachers meanwhile 500 teachers which equal to $79.5 \%$ were female teachers. In terms of age, most respondents in this study consisted of teachers aged between 45 and 49 years (23.7\%), followed by teachers aged 40 to 44 years (17.3\%), 35 to 39 years (16.9\%), 50 to 44 years $(15.7 \%)$, 30 to 34 years $(15.6 \%), 25$ to 29 years $(5.6 \%)$ and 55 to 60 years $(5.2 \%)$.

Most teachers had more than 21 years of teaching experience $(42.1 \%)$, followed by teachers with 16 to 20 years of teaching experience $(19.1 \%), 11$ to 15 years $(17.6 \%), 6$ to 10 years $(15.3 \%)$ and the shortest was teachers who had teaching experience of 1 to 5 years $(5.9 \%)$.

In terms of length of service under the current principals, most teachers served under the leadership of principals ranged in less than one year $(34.8 \%)$, followed by 2 to 3 years $(39.6 \%)$, followed by 4 to 5 years $(16.5 \%)$, over 8 years $(4.6 \%)$ and 6 to 7 years $(4.5 \%)$.

The average teachers involved owned a bachelor's degree (84.9\%), master degree (12.6\%), STPM / Certificate / Diploma (1.7\%) and teachers with a doctorate degree of $0.8 \%$. In terms of professional approvals, 279 or $44.4 \%$ of teachers had an undergraduate degree and Diploma of Education $(23.4 \%)$, Graduate Teacher Training Course (KPLI) $(21.8 \%)$ and Teacher Certificate $(10.5 \%)$. The teachers' information can be seen in Table 3

Table 3. Teacher Demographics Information

\begin{tabular}{|c|c|c|}
\hline Demographics & Frequencies & Percentage \\
\hline $\begin{array}{c}\text { Gender: } \\
\text { Male } \\
\text { Female }\end{array}$ & $\begin{array}{l}129 \\
500\end{array}$ & $\begin{array}{l}20.5 \% \\
79.5 \%\end{array}$ \\
\hline $\begin{array}{l}\text { Age: } \\
25 \text { to } 29 \text { years old } \\
30 \text { to } 34 \text { years old } \\
35 \text { to } 39 \text { years old } \\
40 \text { to } 44 \text { years old } \\
45 \text { to } 49 \text { years old } \\
50 \text { to } 54 \text { years old } \\
55 \text { to } 60 \text { years old }\end{array}$ & $\begin{array}{c}35 \\
98 \\
106 \\
109 \\
149 \\
99 \\
33 \\
\end{array}$ & $\begin{array}{c}5.6 \% \\
15.6 \% \\
16.9 \% \\
17.3 \% \\
23.7 \% \\
15.7 \% \\
5.2 \% \\
\end{array}$ \\
\hline $\begin{array}{l}\text { Length of service with principal } \\
\text { Belownbsn } 1 \text { year } \\
2 \text { to } 3 \text { years } \\
4 \text { to } 5 \text { years } \\
6 \text { to } 7 \text { years } \\
\text { More than } 8 \text { years }\end{array}$ & $\begin{array}{c}219 \\
249 \\
104 \\
28 \\
29\end{array}$ & $\begin{array}{c}34.8 \% \\
39.6 \% \\
16.5 \% \\
4.5 \% \\
4.6 \% \\
\end{array}$ \\
\hline $\begin{array}{c}\text { Teaching Experiences: } \\
1 \text { to } 5 \text { years } \\
6 \text { to } 10 \text { years } \\
11 \text { to } 15 \text { years } \\
16 \text { to } 20 \text { years } \\
\text { More than } 21 \text { years }\end{array}$ & $\begin{array}{c}37 \\
96 \\
111 \\
120 \\
265\end{array}$ & $\begin{array}{c}5.9 \% \\
15.3 \% \\
17.6 \% \\
19.1 \% \\
41.1 \%\end{array}$ \\
\hline $\begin{array}{c}\text { Education Levels: } \\
\text { STPM/Diploma } \\
\text { Degree } \\
\text { Master Degree } \\
\text { PhD } \\
\end{array}$ & $\begin{array}{c}11 \\
534 \\
79 \\
5\end{array}$ & $\begin{array}{c}1.7 \% \\
84.9 \% \\
12.6 \% \\
0.8 \% \\
\end{array}$ \\
\hline $\begin{array}{c}\text { Professional Certificates: } \\
\text { Certificate of Teaching } \\
\text { Education diploma } \\
\text { Post Graduate Diploma } \\
\text { Degree with Education }\end{array}$ & $\begin{array}{c}66 \\
147 \\
137 \\
279 \\
\end{array}$ & $\begin{array}{l}10.5 \% \\
23.4 \% \\
21.8 \% \\
44.4 \%\end{array}$ \\
\hline
\end{tabular}

\section{Quantitative Findings}

The findings from this study showed that teachers give principals the perception of practicing sustainable leadership in their schools at high levels in all dimensions. If viewed in-depth, the dimension - Focus on pupils shows the highest level of practice (mean of 4.6) meanwhile the lowest level of practice (mean 4.37) is the dimension of teaching and learning aspect as described in Table 4. 
Table 4. Mean score for Sustainable Leadership

\begin{tabular}{|l|c|c|c|}
\hline Dimensions & Mean & Standard Deviation & Level \\
\hline Focus on Pupils & 4.60 & 0.43 & High \\
\hline Lateral Capacity Building Through Networks & 4.58 & 0.41 & High \\
\hline Sustain Work Positive Environment & 4.40 & 0.50 & High \\
\hline Deep Learning & 4.37 & 0.50 & High \\
\hline Intelligent Accountability and Vertical Relationships & 4.57 & 0.45 & High \\
\hline Commitment to Changing Context At All Level & 4.56 & 0.45 & High \\
\hline
\end{tabular}

Based on this finding, teachers have been given high levels of perception that principals have been implementing sustainable leadership by focusing primarily on student achievement to bridge the gap between clever and weak students. The principals have focused on teachers' needs to improve the quality of teaching and learning by encouraging teachers to share their expertise and skills in a subject. Leadership aspects are shared with other teachers. In addition, principals also emphasized positive aspects of a working environment, working context and culture as well as the depth of teaching and learning aspects of teachers in the classroom. These six dimensions have a high level of practice carried out by principals in ensuring that they preserved the school's excellence.

The high level of sustainable leadership practice that has been gained through this study explained that the principals in the researched schools had several characteristics that were uniform in performing their duties and responsibilities as a principal. Among the features of such sustainable leadership practiced by principals were trust, effective communication, strategic thinking, crisis-winning skills, togetherness, and exemplary which made them different from other school leaders in order to maintain school excellence.

\subsection{Qualitative Findings}

Qualitative findings supported three critical success factors in sustainable leadership namely; Sustain Work Positive Environment, Commitment to Changing Context at All Levels, and Deep Learning.

The first factor has found three key practices namely a) emphasizing trust; b) effective communication and c) open mindedness. Trust is a pillar of sustainable leadership. This is explained through the following statements:

"I emphasize trust .. trust, the team is in a relaxed situation while we work hard." (PA)

"Ooo .. Very important trust. If the teachers have trusted us, it's good." (PC)

"That is correct. I agree that the trust must exist. If people do not believe how he wants to come with us.?" $(P D)$
Meanwhile, effective communication is a key practice in sustainable leadership. This statement is supported in the respondents' words:

"Connection (communication) with the teachers is always there to know. Sometimes you have a few questions but it's important that you always have a connection " (PA)

"We like as a family in school. That's a way I think everyone should do as a family when working in an organization." (PC)

"So, principals will discuss together. Do you agree? If you agree, just take it to contact time. It's not a decision he's a man .. ".(GAl)

Hence, open-mindedness and willing to accept teachers' opinions and ideas are also factors of sustainable leadership as stated in the statement:

"There is a teacher's involvement in the discussion. At the same meeting, the principal is open-minded. "(GB2) "..Principals can accept the opinions of others. The way he likes is open, not an autocratic type. Can be discussed".(GD2)

The second factor, Commitment To Changing Context at All Levels are divided into three sections - the change in the way as well as the work culture of teachers, the principals think strategically and the principals work to preserve the excellence of the school he leads. The change in the way and work culture of the teacher can be supported by the statement:

"We cannot achieve what we do not want to make changes to the way we work."(GB1)

"...The principal is speaking in meetings, he wants the teachers to change their respective work culture to get better. She said, if the teacher can change, the school can be excellent ". (GD2)

"...The change from the MOE goes a long way to school, so we have to get the chance to achieve our target. Dynamic education so we have to change. Like now, KPM is focusing on 21st-century education ". (PA)

Furthermore, strategic thinking and approaches are challenges in the transformation process of public education in Malaysia [24]. Principal strategic thinking is supported by such statements as: 
"... So when we make a big meeting and then we see that thing is not running ... we call a small meeting. We ask what constraint you ...? "(PA)

"We make follow up follow through. It's okay, to make sure any planning we make can do a good job. "(PC)

"The principal always mentioned in the meeting, she wants the school's excellence, not two years, but she wants to sustain." (GBI)

Meanwhile, the principals who try to preserve the excellence of the school they led can be observed in the statement:

"..correct, if not then you can fall. It's better to work and look at any part of the game. " (GC1)

"A variety of academic programs he wants to make sure the school can go to the next level. Not easy to get to this level.

So we all got the effort to keep the excellence and whether we could go back to the band 2 (laughter) ". (GD2)

The third factor is the deep learning aspect which can be divided into three- principals emphasize curriculum aspects, principals emphasize selection of teaching materials and quality training books for pupils using, and additional focus classes.

Sustainable leadership showed that principals emphasize the curriculum aspect in their respective schools. This is evident in the statement:

"..principals are very focused on curriculum activities.

Indeed, he cares about the subject of these students."
(GA2/GCl/GD1)

"... principals look at all aspects, but the curriculum is indeed the number one. His priority is the curriculum ". (GD2)

Furthermore, principals are also concerned with the selection of teaching materials and training books used by students. This is clear in these statements:

"... Like the book, I was sitting with the teacher. Look at that content.(PA)

"I can't just seat the room alone. The principal wants to know what is going on in the classroom, what the teacher wants to teach, what is the method he uses for the kids to understand. We need to care about that too." (PD)

Meanwhile, an additional focus group is also one of the principals' sustainable leadership skills that emphasize the depth of teaching and learning depth. This can be translated in the statement:

"... I also meet with Mathematics and Science teachers for PT3. I look at the GPMP. So, we set an extra class to create additional classes according to the target group."( $P B)$

"I explained to my teachers, our extra classes must be meaningful, meaning focusing. "(PC)

In conclusion, these three factors of qualitative findings support quantitative findings. Each factor of these qualitative findings also produced three sub-themes. The overall qualitative finding is explained as in Table 5. 
Table 5. Summary of Sustainable Leadership Qualitative Findings

\begin{tabular}{|c|c|c|c|}
\hline Construct & Indicator & Respondent & Descriptor \\
\hline \multirow[t]{25}{*}{$\begin{array}{l}\text { Sustainable } \\
\text { Leadership }\end{array}$} & $\begin{array}{l}\text { Sustain Work Positive } \\
\text { Environment }\end{array}$ & & \\
\hline & Emphasize of trust & PA & $\begin{array}{l}\text { "I emphasize trust ... trust, the team is in a relaxed situation while } \\
\text { we work hard." }\end{array}$ \\
\hline & & $\mathrm{PC}$ & $\begin{array}{l}\text { "Ooo... Very important trust. If the teachers have trusted us, it's } \\
\text { good." }\end{array}$ \\
\hline & & PD & $\begin{array}{l}\text { "That is correct. I agree that the trust must exist. If people do not } \\
\text { believe how he wants to come with us?" }\end{array}$ \\
\hline & Communication & PA & $\begin{array}{l}\text { "Connection (communication) with the teachers is always there to } \\
\text { know. Sometimes you have a few questions but it's important that } \\
\text { you always have a connection " }\end{array}$ \\
\hline & & $\mathrm{PC}$ & $\begin{array}{l}\text { "We like as a family in school. That's a way I think everyone should } \\
\text { do as a family when working in an organization." }\end{array}$ \\
\hline & & GA1 & $\begin{array}{l}\text { "So, principals will discuss together. Do you agree? If you agree, } \\
\text { just take it to contact time. It's not a decision he's a man.. ". }\end{array}$ \\
\hline & Open-Minded & GB2 & $\begin{array}{l}\text { "There is a teacher's involvement in the discussion. At the same } \\
\text { meeting. The principal is open-minded." }\end{array}$ \\
\hline & & GD2 & $\begin{array}{l}\text { "..Principals can accept the opinions of others. The way he likes it is } \\
\text { open, not an autocratic type. Can be discussed". }\end{array}$ \\
\hline & $\begin{array}{l}\text { Commitment to Changing } \\
\text { Context At All Levels }\end{array}$ & & \\
\hline & Change Work Culture & GB1 & $\begin{array}{l}\text { "We cannot achieve what we do not want to make changes to the } \\
\text { way we work.". }\end{array}$ \\
\hline & & GD2 & $\begin{array}{l}\text { ".. The principal is speaking in meetings, he wants the teachers to } \\
\text { change their respective work culture to get better. She said, if the } \\
\text { teacher can change, the school can be excellent ". }\end{array}$ \\
\hline & & PA & $\begin{array}{l}\text { "... The change from the MOE goes a long way to school, so we } \\
\text { have to get the chance to achieve our target. Dynamic education so } \\
\text { we have to change. Like now, MOE is focusing on } 21 \text { st century } \\
\text { education ". }\end{array}$ \\
\hline & Strategic Thinking & PA & $\begin{array}{l}\text { ".. So when we make a big meeting and then we see that thing is not } \\
\text { running ... we call a small meeting. We ask what constraint you...? " }\end{array}$ \\
\hline & & $\mathrm{PC}$ & $\begin{array}{l}\text { "We make follow up follow through. Its okay, to make sure any } \\
\text { planning we make can do a good job. " }\end{array}$ \\
\hline & & GB1 & $\begin{array}{l}\text { "The principals are always mentioned in the meeting, she wants the } \\
\text { school's excellence not two years, but she wants to sustain." }\end{array}$ \\
\hline & $\begin{array}{l}\text { Always Remind to Sustain } \\
\text { the Achievements of School }\end{array}$ & $\mathrm{GC} 1$ & $\begin{array}{l}\text { ".. Correct, if not then you can fall. It's better to work and look at } \\
\text { any part of the game." }\end{array}$ \\
\hline & & GD2 & $\begin{array}{l}\text { "A variety of academic programs he wants to make sure the school } \\
\text { can go to the next level. Not easy to get to this level. So we all got } \\
\text { the effort to keep the excellence and if we could go back to the band } \\
2 \text { (laughter)". }\end{array}$ \\
\hline & Deep learning & & \\
\hline & Focus on Curriculum & $\begin{array}{l}\mathrm{GA} 2 / \mathrm{GC} 1 / \\
\mathrm{GD} 1\end{array}$ & $\begin{array}{l}\text { "..Principals are very focused on curriculum activities. Indeed, he } \\
\text { cares about the subject of these students. " }\end{array}$ \\
\hline & & GD2 & $\begin{array}{l}\text { "...principals look at all aspects, but the curriculum is indeed the } \\
\text { number one. His priority is the curriculum ". }\end{array}$ \\
\hline & Good Content of Learning & PA & $\begin{array}{l}\text { ".. Like the book, I was sitting with the teacher. Look at that } \\
\text { content. }\end{array}$ \\
\hline & & PD & $\begin{array}{l}\text { "I can't just seat the room alone. The principal wants to know what } \\
\text { is going on in the classroom, what the teacher wants to teach, what } \\
\text { is the method he uses for the kids to understand too " }\end{array}$ \\
\hline & Extra Classes & $\mathrm{PB}$ & $\begin{array}{l}\text { "... I also meet with Mathematics and Science teachers for PT3. I } \\
\text { look at the GPMP. So, we set an extra class to create additional } \\
\text { classes according to the target group." }\end{array}$ \\
\hline & & $\mathrm{PC}$ & $\begin{array}{l}\text { "I explained to my teachers, our extra classes must be meaningful, } \\
\text { meaning focusing." }\end{array}$ \\
\hline
\end{tabular}




\section{Discussion}

The study was started by quantitative research and supported with qualitative data. Quantitative findings show that Focus on Pupils is the highest level which is 4.60. It is followed by Lateral Capacity Building Through Network (4.58), Intelligent Accountability and Vertical Relationships (4.57), Commitment to Changing Context At All Levels (4.56), Sustain Work Positive Environment (4.40) and Finally Deep Learning (4.37). However, qualitative findings support Sustain Work Positive Environment, Commitment to Changing Context At All Levels, and Deep Learning. On the other hand, sub-theme results support Focus on Pupils, Lateral Capacity Building Through Network, and Intelligent Accountability and Vertical Relationships.

\subsection{Focus on Pupils}

Sustainable Leadership requires focus. The focus of the school is the pupils in the school itself. The success achieved by the pupils will have a huge impact and is closely linked to the success of a school. One of the factors that keep the school sustainable is that schools are focusing on the classroom. This was agreed upon by Fullan[1] and Davies[25] who looked at learning aspects as a priority. The success of producing good pupils is an important factor in the success of a school. Without focus, success will become blurred and harder to achieve. By focusing, success becomes clearer and achievable in the future.

\subsection{Lateral Capacity Building through Network}

Positive and supportive capacities need to be built between teachers. Teachers are always learning with their colleagues to increase their knowledge in learning to enhance the organizational capabilities. The purpose of the organization is also closely linked with the ever-present members of an organization to explore new knowledge among its members. Additionally, they constantly improve their competence in performing in the workplace and implement any modifications in the face of change and competition [26]. As a leader, principals need to encourage teachers to master the broader knowledge.

\subsection{Sustain Work Positive Environment}

Sustainable leadership requires a positive working environment. A positive working environment occurs when principals provide a conducive working environment for teachers to better plan their teaching. Amabile[27] also believed that the working environment influences employees to think and act more effectively. This positive environment is important to stimulate teacher behavior. In addition, principals are also seen to be able to maintain this positive working environment by encouraging teachers to promote innovative ideas in strengthening their teaching effectiveness. This aspect does not only lead to teachers in the same field but can also transpire across subjects and curriculum. This finding is consistent with Taghipour and Dezfuli[28] who found out that a positive work environment is a catalyst for employees to further promote new ideas. There was a significant relationship between innovative and creative behaviors among teachers with school environment [29].

\subsection{Deep Learning}

Teaching and Learning Aspects are an important part of sustainable leadership. In the same sense, this aspect should be given a deep emphasis. Deep learning is an important aspect of sustainable leadership. Students' success is also seen as the teacher's success. Pupils need to be determined to achieve their best academic achievement at school [19]. Davies argued that double focus on teaching and learning at school is a culture in the organization that needs to be highlighted. Discussions among teachers need to be enhanced to reflect the pedagogy they use. From time to time, teachers will feel that this activity will facilitate their work and eventually become their work culture and improve student learning.

\subsection{Intelligent Accountability and Vertical Relationships}

Intelligent accountability with good relationships must exist in sustainable leadership. The interaction between teachers and principals during the leadership sharing process has had a positive impact on teachers' teaching and learning aspects [14]. Leadership in an organization needs to be shared to provide opportunities for organization members to highlight their leadership talents. This is pivotal as training and early exposure before they become real leaders in the future. Leadership among principals is an important factor in the success of a school and students.

\subsection{Commitment to Changing Context at All Levels}

As a school leader who practices sustainable leadership, teachers need to be encouraged to participate in innovation competitions in curriculum and co-curricular aspects. Indirectly, this will trigger and promote the idea of innovation in the subjects taught to students. This finding is in line with the research conducted by Sheng [30] who showed that high-potential employees in generating, promoting and realizing activities related to creativity and innovation in their work will perform more effectively if they obtain solid support from the organization. This is supported by the findings of Cummings and Worley [31] that depicted innovation in an organization is assisted by elements such as systems and culture as well as behavior within the organization itself. 
This means both principals and teachers have a role in ensuring that innovation activities in the classroom take effect.

\section{Conclusions}

The conclusions from this study have identified key factors in sustainable leadership. This factor needs to be understood by principals who are in excellent schools. Sustainability is needed to maintain the excellence of the school. This study has successfully investigated the critical success factor of sustainable leadership for a school that has achieved excellence in Malaysia. Hopefully, this study will be able to contribute to the policy maker on the awareness of creating a diversity of educational leadership in schools. The basic point in policy making is equated as the desire to create and build an ideal harmonious nation and society [32]. Planning education policies can be balanced with the information provided in this study.

\section{REFERENCES}

[1] M. Fullan. Leadership \& sustainability: System thinkers in action. Corwin Press; 2005.

[2] Z. Waheed, S. Hussin, MI. Khan, S. Ghavifekr, W. Bahadur. Ethical leadership and change: A qualitative comparative case study in selected Malaysian transformed schools. Educational Management Administration \& Leadership. $2019 \mathrm{Jul} ; 47(4): 624-39$.

[3] GC. Avery, H. Bergsteiner. Sustainable leadership practices for enhancing business resilience and performance. Strategy \& Leadership. 2011 May 10; 39(3):5-15.

[4] J. McCann, Sweet M. The perceptions of ethical and sustainable leadership. Journal of Business Ethics. 2014 May 1; 121(3):373-83.

[5] LG. Lambert. Lasting leadership: Toward sustainable school improvement. Journal of Educational Change. 2007 Dec 1; 8(4):311-22.

[6] Clarke S, Stevens E. Sustainable leadership in small rural schools: Selected Australian vignettes. Journal of Educational Change. 2009 Nov 1; 10(4):277.

[7] R. Hardie. Principals' perceptions of the essential components of sustainable leadership and implications for succession planning at the elementary school level: A mixed methods research study (Doctoral dissertation, University of Saskatchewan).

[8] JW. Cook. Sustainable School Leadership: The Teachers' Perspective. International Journal of Educational Leadership Preparation. 2014 Mar; 9(1):n1.

[9] A. Hargreaves, D. Fink. The Three Dimensions of Reform. Educational leadership. 2000; 57(7):30-3.

[10] P. Hallinger, R. Heck. Can leadership enhance school effectiveness. Educational management: Redefining theory, policy and practice. 1999 Sep 8:178-90.

[11] P. Hallinger, M. Lee. Exploring principal capacity to lead reform of teaching and learning quality in Thailand. International Journal of Educational Development. $2013 \mathrm{Jul}$ $1 ; 33(4): 305-15$.

[12] Kementerian Pendidikan Malaysia. Pelan pembangunan pendidikan Malaysia 2013-2025. [Malaysia Educational Blueprint] Online) (www. moe. gov. my). 2013.

[13] S. Kruse, KS. Louis, A. Bryk. Building professional community in schools. Issues in restructuring schools. 1994; 6(3):67-71.

[14] A. Hargreaves. Teaching in the knowledge society: Education in the age of insecurity. Teachers College Press; 2003.

[15] AP. Hargreaves, DL. Shirley. The fourth way: The inspiring future for educational change. Corwin Press; 2009 Aug 11.

[16] M. Fullan, L. Sharratt. Sustaining leadership in complex times: An individual and system solution. Developing sustainable leadership. 2007 Apr 12:116-36.

[17] VL. Clark, JW. Creswell. Student study guide to accompany Creswell's educational research: planning, conducting, and evaluating quantitative and qualitative research. Merrill; 2005.

[18] S. Messick. Validity of psychological assessment: Validation of inferences from persons' responses and performances as scientific inquiry into score meaning. American psychologist. 1995 Sep; 50(9):741.

[19] A. Bryman, D. Cramer. Quantitative data analysis with IBM SPSS 17, 18 \& 19: A guide for social scientists. Routledge; 2012 Aug 21.

[20] S. Uma, B. Roger. Research methods for business: A skill building approach. Book. 2003.

[21] JC. Nunally, Bernstein IH. Psychometric theory.

[22] J. Cohen. Statistical power analysis for the behavioral sciences. Routledge; 2013 May 13.

[23] HH. Ahmad. Implementation of strategic education policy plan at micro-level contexts: Management and leadership challenges. MOJEM: Malaysian Online Journal of Educational Management. 2017 Sep 7; 2(2):1-21.

[24] Davies B, Brighouse T, Passionate leadership in education. Sage; 2008 Aug 21.

[25] M. Dogson. Technological collaboration in industry.

[26] TM. Amabile. How to kill creativity. Boston, MA: Harvard Business School Publishing; 1998 Sep 1.

[27] A. Taghipour, ZK. Dezfuli. Innovative behaviors: Mediate mechanism of job attitudes. Procedia-social and behavioral sciences. 2013 Jul 9; 84:1617-21.

[28] B. McCharen, J. Song, J. Martens. School innovation: The mutual impacts of organizational learning and creativity. Educational Management Administration \& Leadership. 2011 Nov; 39(6):676-94.

[29] Z. Sheng. The Scientific Problems with the Mega 
Infrastructure Construction Management Theory. In Fundamental Theories of Mega Infrastructure Construction Management 2018 (pp. 185-352). Springer, Cham.

[30] CS. Chang, S. Klasky, J. Cummings, R. Samtaney, Shoshani A, Sugiyama L, Keyes D, Ku S, Park G, Parker S, Podhorszki N. Toward a first-principles integrated simulation of tokamak edge plasmas. In Journal of Physics: Conference Series 2008 (Vol. 125, No. 1, p. 012042). IOP
Publishing.

[31] Tang SF, Hussin S. Advancing sustainability in private higher education through quality assurance: A study of two Malaysian private universities. Asian Social Science. 2013 Sep 1; 9(11):270. 